\title{
PETROLEUM SOURCE ROCK CHARACTERIAZATION AND HYDROCARBON GENERATION, BAKU ARCHIPELAGO, SOUTH CASPIAN BASIN, AZERBAIJAN
}

\author{
Javadova A.S. \\ Institute of Oil and Gas, Azerbaijan National Academy of Sciences \\ 9, F.Amirov ave., Baku, AZ1000, Azerbaijan: ajavadova@yahoo.com
}

Keywords: oil, gas, formation, geochemical studies, biomarkers, migration, South Caspian Basin

\begin{abstract}
Summary. The South Caspian Basin (SCB) is known as one of the oldest oil and gas producing regions in the world. It has more than 100 years of hydrocarbon exploration and development history but still holds large volumes of unexplored resources. To date, a large number of research projects have been carried out to better understand the basin's development history and thereby to assess and unlock the remaining hydrocarbon potential. Recent geological exploration programs that been carried out in the region have introduced great opportunity to access to the subsurface data, both seismic and drilling, from the areas that never been explored so far. They have played a critical role in mapping subsurface challenges and in more accurate, targeted approach to planning future exploration and development programs in the area. The purpose of this article is to present the results of geochemical studies, geological and geochemical analysis, correlations in the system oil - source rock - mud volcanoes ejecta - well data carried out to describe the history of hydrocarbon fluid formation in the basin, potential mechanisms of hydrocarbon generation and migration as well as geological time of formation and accumulation of hydrocarbons in structural traps. The results of geological and geochemical analysis support the deep origin and genetic identity of the oil and gas samples analyzed. Hydrocarbon formation and migration mechanisms in the area are controlled by pressure regime within the source-rock with respect to its surrounding environment of permeable beds. The changes and trends observed in the chemical composition, geochemical properties of the hydrocarbons fluids support the importance of seal capacity, impact of the overlaying cap rocks on type of hydrocarbon fluids and nature of hydrocarbons traps in the area. The timing of petroleum generation from the source rock is consistent with the timing of structural development of some of the hydrocarbon traps in the study area.
\end{abstract}

(C) 2021 Earth Science Division, Azerbaijan National Academy of Sciences. All rights reserved.

\section{Introduction}

The South Caspian Basin is known as one of the world's most prolific oil and gas basins. It is a sedimentary basin with more than $20 \mathrm{~km}$ of Mesozoic and Tertiary sediments deposited on oceanic or thinned continental crust. Recent rapid burial has resulted in low geothermal gradients that support potential to generation of hydrocarbons at great depth between $8-10 \mathrm{~km}$. Compressional deformation in the late Pliocene with reactivated tectonics led to formation of local uplifts and onset of major folding in the basin. Organic rich formations of Oligocene-Miocene age, predominantly Diatom and Maykop, are the principal oil-prone source rocks proved in the basin. Reservoirs are mainly the Pliocene age Productive Series (PS) formations. Outcrop studies suggest that these reservoir units were deposited in non-marine environment ranging from fluvial to lacustrine delta (Reynolds et al., 1998). Distribution and quality of organic matter within the SCB is very strongly influenced by depositional setting. Integrated interpretation of the geochemical data shows that hydrocarbons in the area of study belong to the same, or similar genetic family with good correlation with the biological markers identified in the hydrocarbon fluids analyzed. Hydrocarbon formation and migration mechanisms in the area are controlled by pressure regime within the source-rock with respect to its surrounding environment of permeable beds. In our opinion, the main pulse of hydrocarbons migration occurred in recent geological time (Absheron, Quaternary) and there are direct indicators (natural seeps, active mud volcanoes expelling oil and gas) 
proving that the migration of hydrocarbons in the area is still taking place. Baku archipelago is the focus area in this current study. It covers western shelf zone of the Azerbaijan sector of the Caspian Sea and represents a south-eastern extension into the sea tectonic zones of the South Gobustan and Lower-Kura depressions. Currently, Baku archipelago is one of the main oil and gas producing area in the basin with promising exploration opportunities as well (Fig. 1).

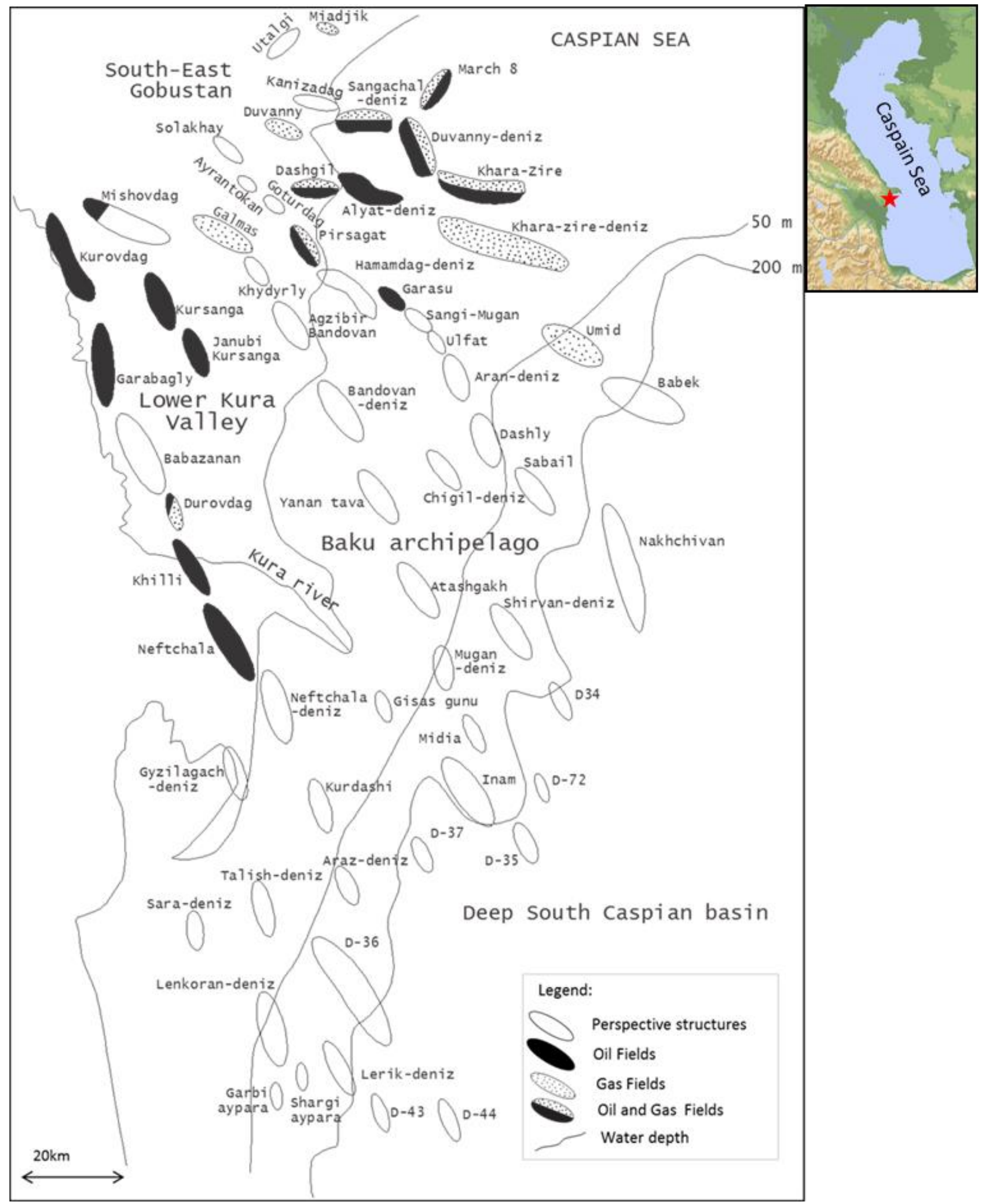

Fig. 1. Location map - Baku archipelago perspective structures and oil and gas fields 
Baku archipelago represents south-east extension of the South-East Gobustan and Lower Kura depressions into the Caspian Sea. In general, there is trend in south-east direction with regional deepening of the subsurface units and change in type of hydrocarbon fluids phase from oil and gas to gas, gascondensate deposits. Principal hydrocarbon reservoirs are Pliocene age Productive Series (PS) formations that are deposited unconformably above a marine Miocene shale sequence that contains organic rich Diatomaceous shale sequence (Fig. 2).

\begin{tabular}{|c|c|c|c|}
\hline EPOCH & \multicolumn{2}{|c|}{ FORMATION } & SUITES \\
\hline RECENT & \multicolumn{2}{|c|}{ QUATERNARY } & \\
\hline PLIESTOCENE & \multicolumn{2}{|c|}{ ABSHERON } & \\
\hline \multirow{10}{*}{ PLIOCENE } & \multicolumn{2}{|c|}{ AKCHAGYL } & \\
\hline & \multirow{9}{*}{$\begin{array}{l}\text { PRODUCTIVE } \\
\text { SERIES }\end{array}$} & \multirow{2}{*}{ UPPER } & SURAKHANY \\
\hline & & & SABUNCHY \\
\hline & & \multirow[b]{2}{*}{ MIDDLE } & BALAKHANY \\
\hline & & & FASILA \\
\hline & & \multirow{5}{*}{ LOWER } & QUG \\
\hline & & & QUQ \\
\hline & & & QLd \\
\hline & & & QA \\
\hline & & & Qala \\
\hline \multirow{4}{*}{ MIOCENE } & & & PONTIAN \\
\hline & & & DIATOMACEOUS \\
\hline & & & SPIRIALITIC \\
\hline & & & \multirow[t]{2}{*}{ MAYKOP } \\
\hline \multirow[t]{2}{*}{ PALEOGENE } & & & \\
\hline & & & \\
\hline
\end{tabular}

Fig. 2. Study Area - Simplified stratigraphic chart

Commercial deposits of oil and gas-condensate have been identified here in the Horizons V, VII, VIII of Pliocene age Middle productive series formations. Lithologically they represent a series of alternating sandstone, mudstone and siltstone layers. Fluvial deposits in the lower Productive Series below the Fasila formation provide additional targets. Regarding to the formation mechanisms of hydrocarbons in the Productive Series formations, historically there were two main concepts developed on this subject. According to the first one (first described by Gubkin (Губкин, 1937), oil and gas deposits in the PS are formed as a result of migration of hydrocarbons from the deeper Oligocene-Miocene strata, predominantly from the Diatom and Maykop formations. According to the second concept, oil and gas deposits in PS are singenetic to accommodating deposits, with Lower PS (Qala, Qirmaky (QLd) and Qirmakiustu (QUQ, QUG) formations considered to be source rocks for the HCs accumulation. Later, with access to more precise data, especially from the deeper strata, it has been proved that Lower PS units has never reached temperatures required for the transformation of the organic matter into HCs. Our early research works have shown good match in correlation of key biological markers in the oil and source rock samples taken in offshore Azerbaijan. That suggests that $\mathrm{HC}$ fluids accumulated in the PS belong to the same genetic family with good match to geochemical parameters of the diatomaceous age shale source rock sample that was analyzed. Despite of more than 100 years of hydrocarbon exploration and production history, there are still debates around hydrocarbon formation and migration mechanisms in the SCB (Guliyev et al., 2019; Green et al., 2009; Гулиев и др., 2004; Abrams, Narimanov, 1997; Narimanov et al., 1997; Inan et al., 1997; Мамедов, Джавадова, 1993; Zonenshain, Le Pichon, 1986; Чахмахчев и др., 1974; Старобинец, 1974; Петров и др., 1967; Никонов, 1962; Губкин, 1937). Many researchers admit that the main phase of HC migration into the PS occurred through faults, mud volcanoes channels and diapers. Some of researchers consider the possibility of migration of the $\mathrm{HC}$ fluids in the retrograded gas mixture gas phase, or in a solution in water and partially in a gas phase. Critical role of hydrodynamics in the formation and distribution of $\mathrm{HC}$ accumulations in the SCB was rightly highlighted by many researches historically and that concept has proved itself through detailed modeling done based on new data acquired in the basin recent years. Deep drilling with access to the data from the deeper strata helped a lot better understand thermodynamic story of the basin, map the distribution of the different type of fluids that formed under certain environment as well as identify potential traces of oil and gas migration. Another important issue that been addressed in this paper is the compositional changes of $\mathrm{HC}$ fluids during migration. Organic geochemical parameters based on biomarker distribution and stable carbon isotopes have been applied to understand the source and thermal maturity of the organic matter as well as depositional environment of the potential source rock in the area of study (Goodwin et al., 2020; Guliyev et al., 2019; Peters et al., 1993; Radke, Welte, 1983; Seifert, Moldovan, 1980; ten Haven, Rullkotter, 1988).

\section{Materials and methods}

To address the issues described above precise geochemical analyses have been carried out on selected oil and gas samples from the fields in the area of Baku archipelago, including Sangachaly-deniz - Duvannydeniz - Khara-zire, Alyaty-deniz, Bulla-deniz, Garasu, 8 March fields. In total 40 fluid samples have been analyzed. Samples represent reservoir units of Productive Series and Oligocene-Miocene, particularly diatomaceous age shale sample (Sangachaly-deniz, well\# 534) that is proven to be principal source rock for the 
hydrocarbons in the study area. Biomarker compounds in the fraction of saturated compounds $\mathrm{C}_{15+}$ were studied using the gas-chromatograph 5690 in conjunction with mass spectrometer 5970. The separation of the saturated fractions was carried out with the help of a 50-meter column of PR. After the insemination at 270 volatile compounds were refocused for 4 minutes at $50^{\circ} \mathrm{C}$. Helium was used as a gas-carrying. The mass spectrometer worked in electronic ionization mode. Data were collected on single ions.

\section{Results and discussion}

The distribution of $\mathrm{C}_{15+}$ saturate fraction gas chromatograms in hydrocarbon fluids analyzed show relatively uniform behavior throughout the study area with some local differences that will be dis- cussed later in paper (Fig. 3). In general, offshore oils show predominant amount of saturated hydrocarbons (68\%), with $20 \%$ of aromatic, $11 \%$ polar and $1 \%$ of asphaltenes.

Understanding the $\mathrm{HC}$ generation and formation mechanisms requires good understanding of basin formation, depositional environment through geological time and access to the critical data that may help to identify the biological input and age of the potential source rocks. Below are learnings from the distribution of the key biomarkers and biomarkers ratios that helped us to understand the issues described above (Peters et al., 1993; Radke et al., 1983; Seifert et al., 1983). Distribution of steranes in the oils analyzed show a strong predominance of $\mathrm{C}_{27}$ and $\mathrm{C}_{28}$ steranes relative to $\mathrm{C}_{29}$ steranes (Fig. 4).
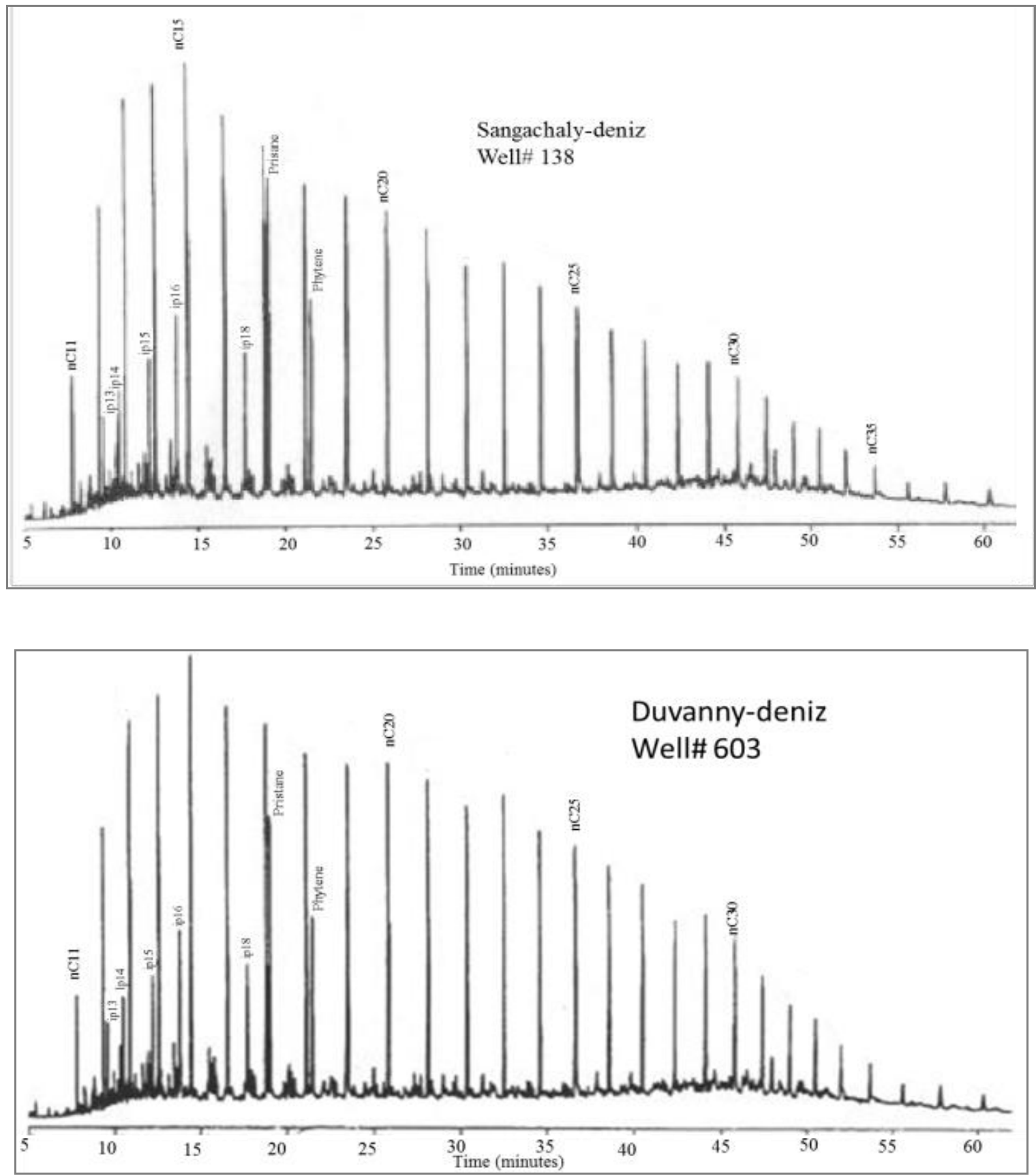

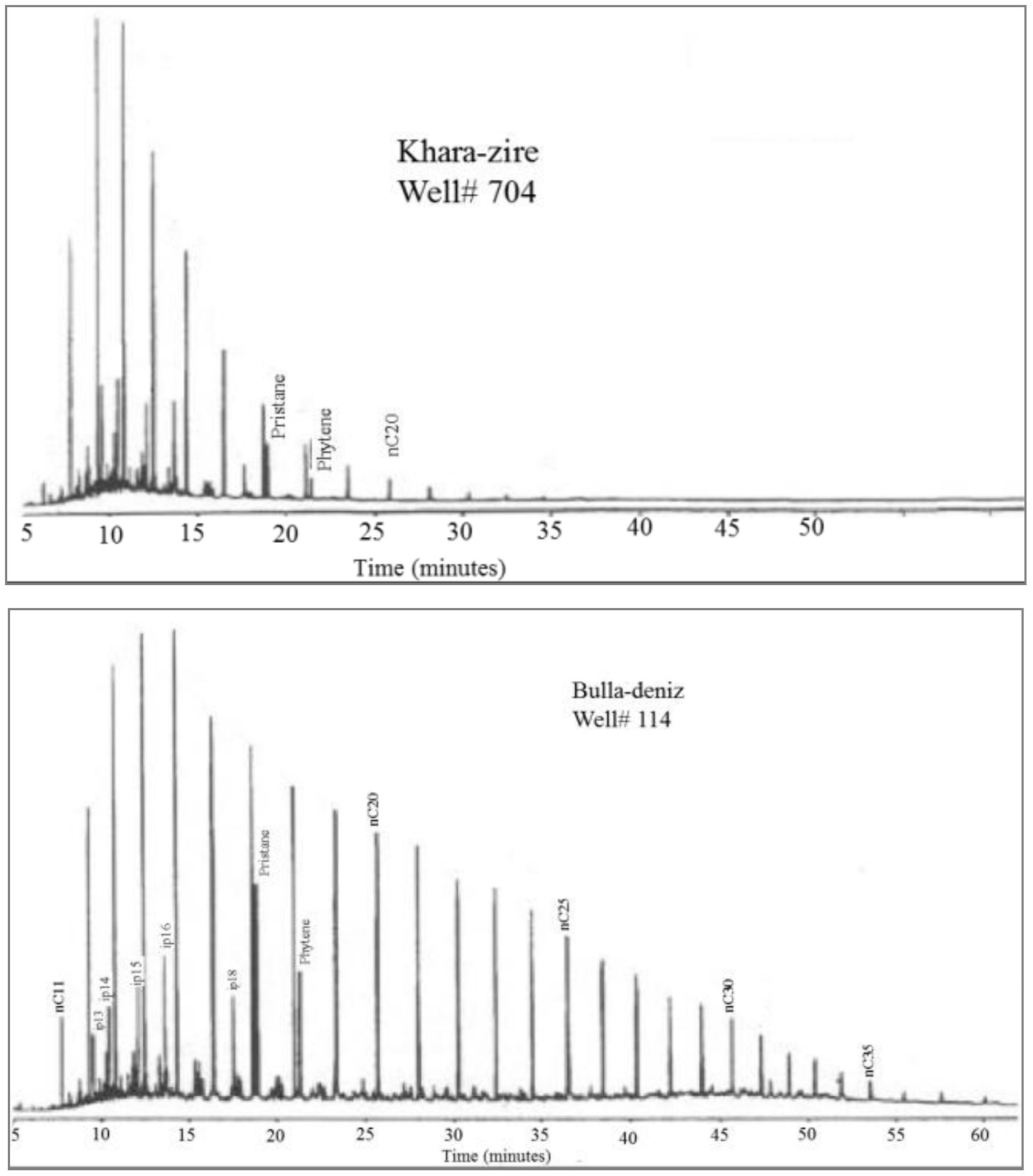

Fig. 3. Baku archipelago fields representative $\mathrm{C}_{15+}$ saturate fraction gas chromatograms

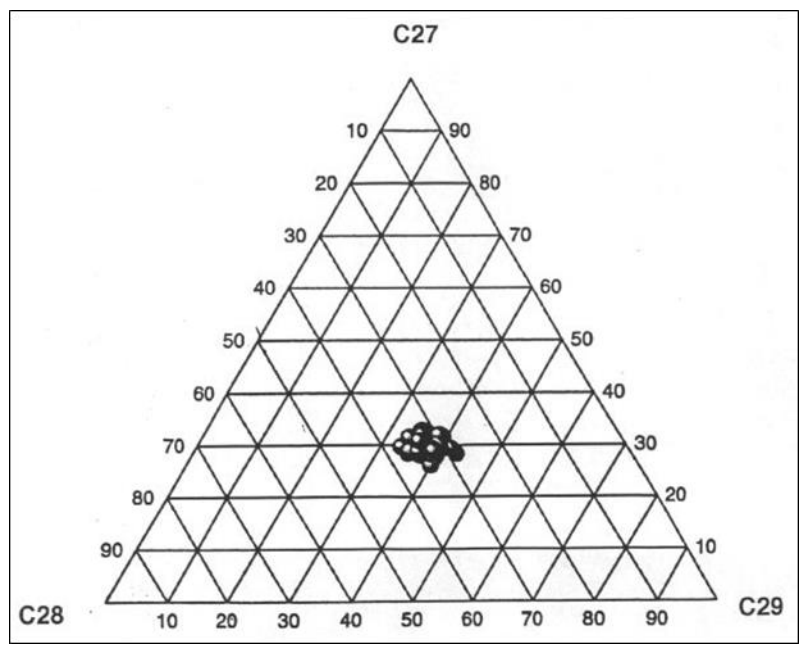

Fig. 4. Baku archipelago fields - Steranes, diasteranes distribution
Grantham and Wakefield (1988) have shown that there is relationship between distribution of sterols and geological age. According to their observations, the ratio of steranes $\mathrm{C}_{28} / \mathrm{C}_{29}$ in oils and bitumen less than 0.5 is typical for lower-Paleozoic and older sediments, between 0.5-0.7 - for deposits from upper Paleozoic to Jurassic and more than 0.7 - for Cretaceous and younger sediments. Such variation of sterols over geological time is explained by changes taking place as a result of chemical transformations through biological evolution and the processes of biosynthesis over geological time. Volkman (1986) discovered that green algae were particularly enriched with ethyl-cholestanes. During the biological evolution, phytoplankton microorganisms became increasingly diverse. It is known that $\mathrm{C}_{28}$ sterols are 
synthesized mainly by dinoflagellates, coccolithophorids and diatoms. Enrichment of $\mathrm{C}_{28}$ steranes is not associated with the emergence of some new organisms, but with an increase in the diversity of phytoplanktons. The $\mathrm{C}_{28} / \mathrm{C}_{29}$ ratio in $\mathrm{HC}$ fluids of the study area ranges from 0.76 to 1.10 with an average value of 0.86 . The relatively high content of steranes $\mathrm{C}_{28}$ in comparison to $\mathrm{C}_{27}$ and $\mathrm{C}_{29}$ shows that diatom algae were an essential component of the "primary" phytoplanktons produced. This is support above mentioned observations by Grantham and Wakefield (1988) and indirectly indicates that the source rocks in the study area are correspond to the Tertiary and possibly Mesozoic age sediments. One of the important geochemical criteria is Hopane/HopaneMoretane ratio. It is used as an indicator of thermal maturity, hydrocarbon formation environment as well as source. There is direct relationship in distribution of hopane/hopane-moretane ratio and maturity of OM, i.e. increase in maturity will lead to increase in the ratio (Seifert and Moldovan, 1980). By Grantham (1986) there is also good correlation between hopane/hopane+moretane ratio and geological age. Most pre-Middle Cretaceous oils showed relatively low value of this ratio. The oils generated by the upper Cretaceous and Tertiary source rocks have high abundance of hopanes. The average value of hopane/hopane+moretane ratio in the oils and condensates of the study area is 0.87 , ranging from 0.84 to 0.89 (Fig. 5). This suggests that oils and condensates in the study area were generated by source rocks of Tertiary, and possibly Mesozoic age, with thermal maturity corresponding to the Main Oil Generation zone, i.e. "oil-generative window".

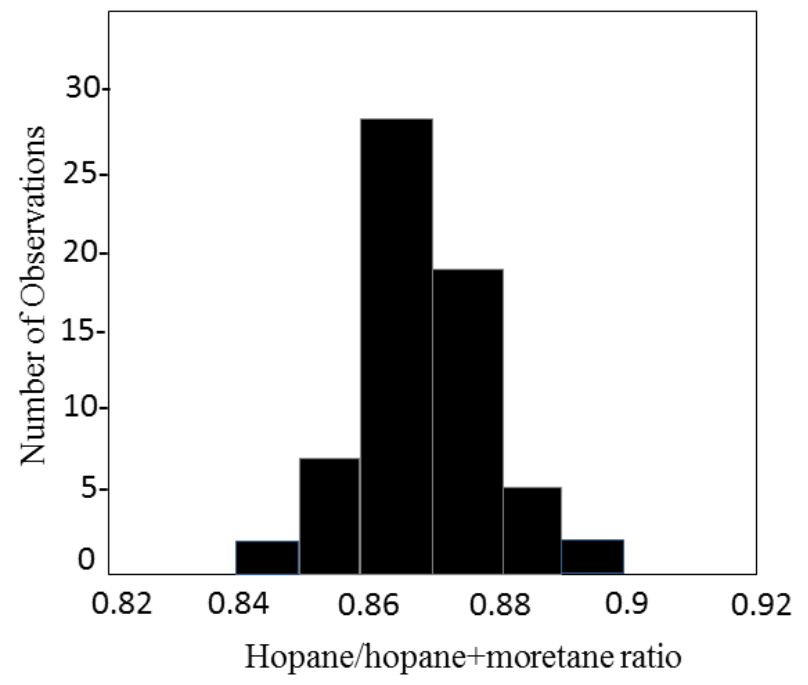

Fig. 5. Baku archipelago fields - distribution of maturity depends on $\beta, \alpha$-Moretanes $\mathrm{C}_{29}+\mathrm{C}_{30} / \beta, \alpha$-Moretanes $+\alpha, \beta$-Hopanes ratio

It is known that $18 \alpha(\mathrm{H})$-oleanane is an indicator of both biological source and geological age. It forms from betulin (Grantham et al., 1983), cockroaches (ten Haven, Rullkotter, 1988) and other pentacyclic triterpenoids (Whitehead, 1973) produced by angiosperms. The ratio of $18 \alpha(\mathrm{H})$ to $18 \beta(\mathrm{H})-$ oleananes depends on the degree of maturity. Riva and his co-authors (1987) have investigated more than 150 oil samples from different oil and gas basins around the world and have identified both isomers. They show that oleananes are present only in upper Cretaceous and Tertiary age sediments. In addition, it was shown that there is clear correlation between $18 \alpha(\mathrm{H})$ and $18 \beta(\mathrm{H})$ - oleananes and maturity of OM, i.e. the ratio will increase with increase of maturity index. All above linked to the fact of presence of oleananes in the oils and condensates of the Baku archipelago indicates that Tertiary, OligoceneMiocene and possibly deeper Mesozoic age source rocks are responsible for $\mathrm{HC}$ generated in the study area (Fig. 6).

Radke and Welte (1983) suggested that the distribution of phenanthrene and four methylphenanthrene isomers could be used as an indicator of catagenic maturity. As the maturity of $\mathrm{OM}$ increases the abundance of 2-methyl and 3-methylphenantrenes relative to abundance of 9-methyl and 1-methylphenantrename decreases, where the ratio of phenanthrene to methylphenanthrenes increases. Radke and Welte suggested that this ratio should be called a methylphenanthrene index (MPI-1) and used through the following equation: $\mathrm{MPI}-1=(2 \mathrm{MP}+3 \mathrm{MP}) /(\mathrm{P}+$ $9 \mathrm{MP}+1 \mathrm{MP})$, where: MP is methylphenanthrene and Pisphenanthrene. Distribution of the methylphenanthrene $(2+3) /(9+1)$, methylphenanthrene index and Vitrinite Reflectance Index in the oils and condensates from the study area ranging as $0.75-1.1,0.47$ 0.8 and 0.55-0.79, respectively (Fig. 7) (Джавадова, 2004).

In studying the formation of oil and gas deposits, it is important to take into account the distribution and relationship in distribution between different types of fluids throughout the study area.

In the study area majority of the oil deposits are associated with eroded, tectonically complicated, faulted areas, in contrast gas accumulations in most cases are linked to the less complicated, deeper structures. The important feature to highlight is the change of the $\mathrm{HC}$ fluids accumulations from the oil to the gas-condensate in south-east direction which coincides with the thickening of regional seals in the same direction. The regional nature of this feature is important geological data that helps to map the areas with high HC potential and plan potential exploration works as well. Timing of trap development in relation to HC generation and expulsion is important in controlling the amount and type of the $\mathrm{HC}$ accumulations. The 
timing of petroleum generation from the Maykop source rock is consistent with the timing of structural development of the productive HC deposits in the study area. A regional pulse of hydrocarbon generation occurs during deposition of the Productive Series and originates as we mention earlier in the deep basin.

Detailed analysis of the timing of development of the individual structural uplifts in the study area suggests that most of the structures in a basin were formed during Late Pliocene-Quaternary time. There are a number of well-studied fields in the South Caspian Sea that can be used to map the stages of migration and accumulation of the hydrocarbon fluids in the basin. This could be done based on reconstruction of paleo-tectonic processes that took place in the basin through geological time and the volume of hydrocarbon accumulations in the traps.

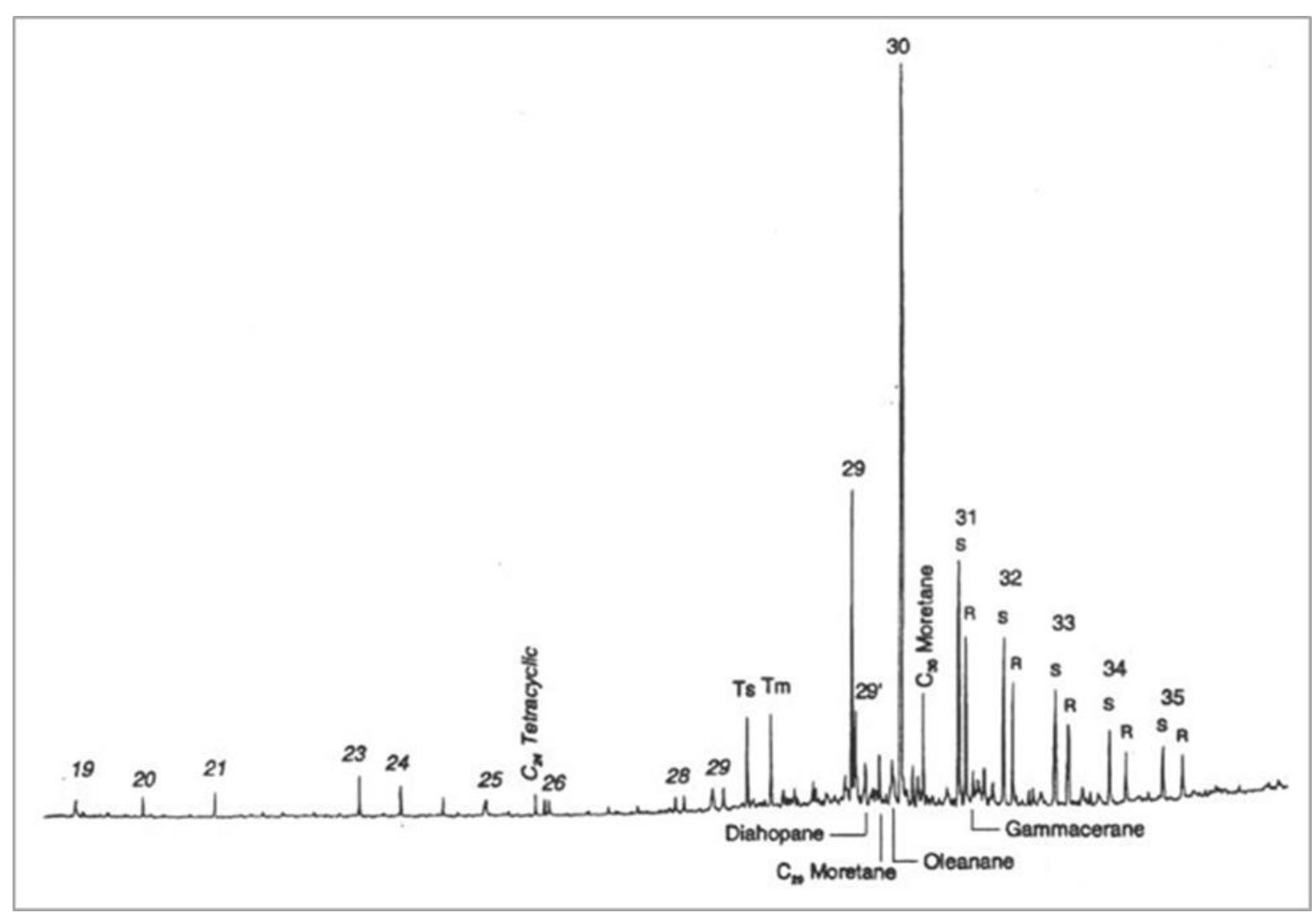

Fig. 6. Baku archipelago - Bulla-deniz field -representative mass fragmentograms showing the distribution of terpanes, hopanes in the oil samples from Baku archipelago field
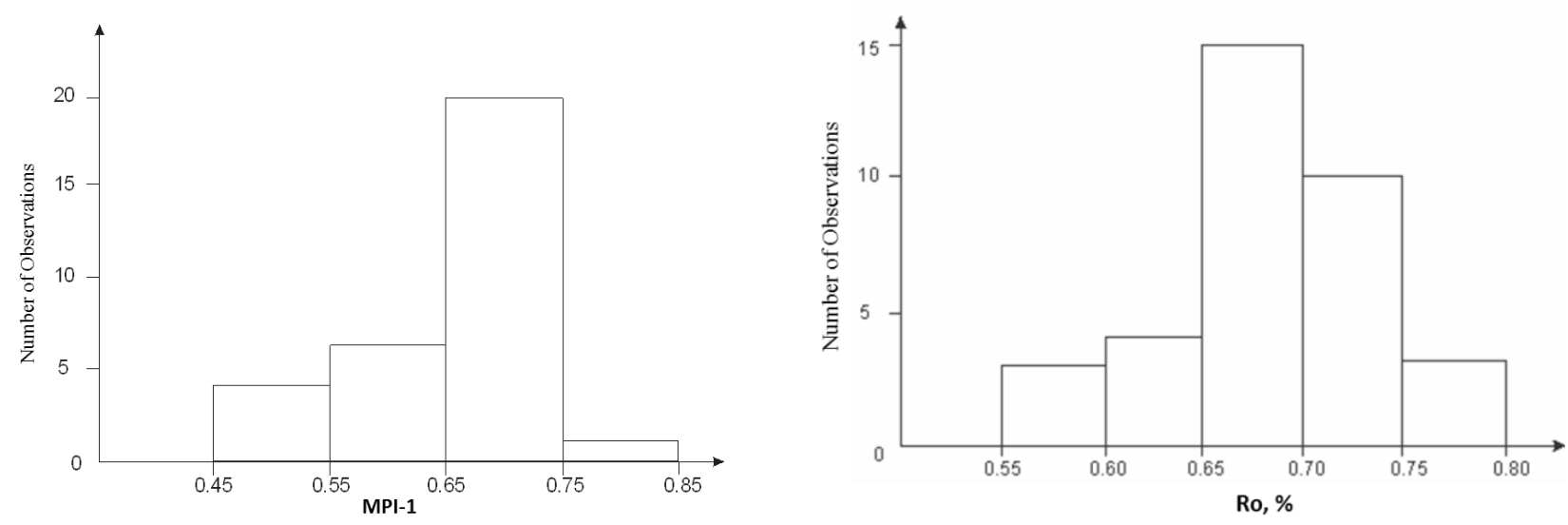

Fig. 7. Baku archipelago fields - distribution of the methylphenanthrene index (A) and Vitrinite Reflectance Index (B) in the oil and condensates 
Modeling results suggest that regional pulse of hydrocarbon generation starts in the deeper part of the basin during deposition of the Productive Series. This pulse of hydrocarbon migration (preAkchagylian) responsible for accumulation of hydrocarbons in the structures existing in the basin by that time, for example Sangachaly-Duvanny, Kharazire trend, at the same time did not effected number of other structures in a basin that had not been developed by that time yet, or had not adequate closure to trap much of this early regional pulse of hydrocarbons prior to the Akchagylian, like Hamamdag, for example. This observation is coinciding with the results of the geochemical analysis (MPI and others) that suggest early generation and expulsion of the hydrocarbons in the study area. Renewed sediment loading during post-Akchagylian time, provokes a second, more focused pulse of petroleum generation in the basin. This second pulse is significant in scale and explains the observed admixture of both biodegraded and non-biodegraded oils in Duvanny and Bulla-deniz, for example, and the lack of large accumulations in the structures, like Hamamdag.

Distribution of the hydrocarbon phases in the study area is as follows: horizon V of Balakhany suite PS is gas-condensate accumulation for the Duvanny-deniz, Khara-zire, Bulla-deniz fields, Fasila suite (horizon VII) is gas and oil in Sanagachalydeniz - Duvanny-deniz - Khara-zire, Alaty-deniz, 8 March, Garasu fields and QUQ suite (horizon VIII) is gas-condensate trap in the Duvanny-deniz, Kharazire, Bulla-deniz, 8 March fields. There is variation in the hydrocarbon phases in the Fasila suite horizon VII which is the main producing horizon in the area. For example, horizon VII in Kanizadag structure is a gas-condensate accumulation but in the south-west direction of regional deepening of the basin there is a clear change in type of fluids accumulated. For example, we observe following distribution in the chain of the Sangachaly-deniz - Duvanny-deniz Khara-zire and Bulla-deniz fields: Sangachaly-deniz - gas and oil, Duvanny-deniz - oil and gas, Kharazire - gas and oil and Bulla-deniz - gas-condensate and oil accumulations. This kind of variation doesn't link to differential regression mechanism by Gassow that doesn't consider potential change in the position of the structures through geological time which is the case in the South-Caspian basin.

Numerous evidences show the dominant role of the vertical migration in the accumulation of hydrocarbons in the Productive Series formation within the study area. Observed vertical hydro-chemical inversion in the Productive Series - the presence of highly mineralized, brackish waters in the upper part of the PS with less-mineralized, alkaline at the lower PS could be explained by upward movement of ul- tra-alkaline waters from the deeper strata up towards PS. This supports the importance of the vertical movements in the process of HC migration. Therefore, it is not unusual that most PS hydrocarbon accumulations in the study area are corresponding to the areas with high concentration of alkaline (zone VII, VIII) and partially mixed waters (zone V). This observation also supports the fact of relatively higher reservoir pressures at the base of PS as a result of introduction of high-pressured fluids escaped from the Oligocene-Miocene shales due to compaction.

There is a clear relationship between chemical composition of the hydrocarbon fluids, their regional distribution and changes along the vertical section in the wells as well. Mud volcanoes also played certain role in the formation of hydrocarbon accumulations in the study area. In overall, the data suggests the dominant role of vertical migration in the formation of $\mathrm{HC}$ accumulations in the study area.

Let's take a quick look at the nature of this phenomenon. One of the geochemical criteria to apply to map hydrocarbons migration pathways is the decrease of saturation pressure with increasing abundance of gas dryness. In our case, for zone VII we see opposite picture - both parameters change proportionally, increasing along both sides of Duvannydeniz field, i.e. for the Duvanny-deniz the value of saturation pressure is $20-30 \mathrm{MPa}$, for the area of Sangachaly-deniz and Khara-zire it varies between 30-40 MPa. Similarly, the dryness of gases, respectively, increases from the Duvanny-deniz (12.36) to the Sangachaly-deniz (14.85) and to the Khara-zire. Such changes could be explained by migration of the hydrocarbons from the deeper strata via tectonic faults. Formation of a gas zones in the areas close to tectonic faults could explain observation above. There are number of mud volcanoes in the study area, including the ones located within the producing oil and gas fields. Correlation of the chemical composition between gas samples from the mud volcanoes and producing reservoir units helps to understand migration mechanisms in the study area. We see high similarity in chemical composition between the gas samples from the producing fields and from the mud volcanoes in the area. Duvanny mud volcano shows $92.35 \%$ of $\mathrm{CH}_{4}$ with $4.19 \%$ of total heavy hydrocarbons, in Khara-zire Island and Khara-zire mud volcanoes these two parameters are $94.11 \%$, $94.77 \%$ for $\mathrm{CH}_{4}$ and $5.01 \%$, $4.8 \%$ for total amount of heavy hydrocarbons respectively. Same parameters for the gas samples from the producing Duvanny-deniz and Khara-zire fields show $92.89 \%$, $94.77 \%$ of $\mathrm{CH}_{4}$ and $6.44 \%, 4.88 \%$ for the total heavy hydrocarbons respectively. That suggests the dominant role of vertical migration in the system. And now let's review the trends we observe in the 
composition of oil and condensates that may help to understand formation and migration of the hydrocarbons in the Baku archipelago.

We see two stages of hydrocarbon migration and accumulation in the area of study. The first stage covers the beginning of the Absheron time, during which regional vertical (and accompanying lateral migration through individual layers) migration was carried out as a single phase, deep faults activated due to intense tectonic movements that time could play a certain role as migration pathways as well. Presence of mud volcano breccia in the deep Miocene-Oligocene deposits (Diatom, Maykop) is a good evidence of that. Migrated hydrocarbons (in Gas-Oil phase) would accumulate in the traps with favorable reservoir properties. At this initial stage the chemical composition of the fluids would be the same across entire basin, regardless of their stratigraphic age.

Later, until the end of the Absheron time preservation or any changes in the chemical compositions of the fluids would depend on sealing capacity of the overburden layers. The second stage of hydrocarbon migration (Gas-Condensate phase) covers the Anthropogenic phase of tectogenesis, during which a structural framework of folds was finally formed. Numerous faults that formed due to reactivated tectonic movements in the area cause compartmentalization of the existing structures and as a result changes in chemical compositions and properties of the hydrocarbon fluids accumulated. It should be noted that at this time, along with the ongoing migration processes, there were significant overflows among and between the layers, leading to the re-formation of existing accumulations. For example, due to the absence of Akchagyl and Lower Absheron deposits on the SW flank and SE uplift zone of the Duvanny-deniz field, i.e., due to low seal capacity before the second stage of migration, there was a partial destruction of the original trap due to diffusion processes. High resistivity in the horizons
$\mathrm{V}$ and VII of Productive Series observed in the wells (\#30, 45, 52, 58, 97) located out of oil-water contact is a good evidence that supports the observation above. It also can indicate lateral migration but that would normally have regional feature, not a limited, local one. The change in the quality of sealing capacity effects on the amount of gas dissolved in oil, as well as the quantity and quality of its gasoline component (fractions up to $200^{\circ} \mathrm{C}$ ); first, paraffinicnaphthenic and then naphthenic-aromatic hydrocarbons would release from the hydrocarbon accumulation. Note that there is a gradual change in the $\sum \mathrm{C}_{5}+\sum \mathrm{C}_{6} / \sum \mathrm{C}_{7}+\sum \mathrm{C}_{8}$ ratio along stratigraphic section, i.e. from the bottom, horizon VIII up to horizon V. It ranges from 0.3-0.5 in horizon VIII and then decreases to 0.2 in horizon $\mathrm{V}$, i.e. up to the well section. In our view, the decrease of this ratio in the horizon $\mathrm{V}$ is well linked to what was stated above and could be explained by loose of light fractions as a result of diffusion. As noted, the initial reservoir pressure of the gas-condensate-oil deposit in the horizon $\mathrm{V}$ of the Duvanny-deniz field ranges between 29.4-32.4 MPa, for the gas-condensate deposit of the horizon VIII the range is $49-59 \mathrm{MPa}$. Experimentally found that under normal conditions (10-20 MPa), model condensates are significantly enriched by those hydrocarbon compounds that easily move into the gas phase. However, at high pressures (30-50 MPa) the effect of selective solution in compressed gases fades, as a result condensates and original oil will have similar chemical composition. This can explain high degree similarity in the chemical composition of different fractions of condensates from horizons V and VIII, although there is a significant difference in hypsometric position (up to $2000 \mathrm{~m}$.) and consequently in subsurface conditions (pressure and temperature) (Table 1). In addition, this once again supports the assumption that hydrocarbon fluids migrated at initial stage of migration would have the same or similar chemical composition.

Table 1

Condensates from Sangachaly-deniz field - similar hydrocarbon composition despite difference in depth and subsurface conditions

\begin{tabular}{|c|c|c|c|c|c|c|c|c|}
\hline \multirow{2}{*}{ Well\# } & \multirow{2}{*}{ Horizon } & \multirow{2}{*}{$\begin{array}{l}\text { Depth, } \\
\text { meters }\end{array}$} & \multirow{2}{*}{ Fractions, ${ }^{\circ} \mathrm{C}$} & \multirow{2}{*}{$\begin{array}{c}\text { Output } \\
\%\end{array}$} & \multirow{2}{*}{ Density } & \multicolumn{3}{|c|}{ Group fractions, Boiling Point $200^{\circ} \mathrm{C}$} \\
\hline & & & & & & Paraffinic & Naphtenic & Aromatic \\
\hline \multirow{4}{*}{298} & \multirow{4}{*}{ V } & \multirow{4}{*}{3327} & Boiling Point-150 & 34.44 & 0.745 & 47.70 & 39.03 & 13.27 \\
\hline & & & $150-200$ & 28.44 & 0.749 & 52.01 & 34.31 & 13.68 \\
\hline & & & $200-250$ & 17.26 & 0.770 & 55.34 & 31.94 & 12.72 \\
\hline & & & $>250$ & 19.86 & 0.781 & 47.12 & 42.03 & 10.85 \\
\hline \multirow{4}{*}{537} & \multirow{4}{*}{ VIIII } & \multirow{4}{*}{5023} & Boiling Point-150 & 30.97 & 0.766 & 45.76 & 40.09 & 14.15 \\
\hline & & & $150-200$ & 15.04 & 0.779 & 52.96 & 33.17 & 13.87 \\
\hline & & & $200-250$ & 15.36 & 0.804 & 52.38 & 34.38 & 13.24 \\
\hline & & & $>250$ & 19.14 & 0.805 & 50.81 & 36.42 & 12.77 \\
\hline
\end{tabular}


It is known that, due to the high mobility, light fractions of the hydrocarbon fluids are successfully used to understand migration processes (Table 2). As can be seen from the Table 2, ¿Cyclohexanes/ $\sum$ Cyclopentanes ratio varies within 2-3. According to V.F.Nikonov (Никонов, 1962) in oils this ratio is equal to or less than 1, in condensates is 3-4 or more, and the change in this ratio within 1-3 indicates the possibility of presence of an oil rim. Consequently, the increase of this ratio with depth (from 2.02 to 2.80 ) is well linked to the distribution of hydrocarbon accumulations in the Baku archipelago, indirectly indicating the presence of an oil rim in the horizon VIII at the Sangachaly-deniz - Duvanny-deniz - Khara-zire and in the horizon VII at the Bulla-deniz field.

In addition to this, geochemical composition of the gasoline fraction from the hydrocarbon fluids demonstrates a clear relationship between subsurface condition, i.e. temperature and pressure in reservoir sections and chemical composition of the fluids migrated in the system. This is reflected by the fact that in the direction of migration of the hydrocarbons the value of the ratios $\sum$ Cyclohexanes/ $\sum$ Cyclopentanes, $\sum$ n.alkanes/ $\sum$ iso.alkanes is decreasing. That is due to the fact that in compressed gases branched alkanes and five-membered naphthenes dissolve noticeably better than n-alkanes and six-membered naphthenes. Therefore, due to phase-retrogradation, chromatographic and diffusion processes, as well as decrease in temperature and pressure in the system, the hydrocarbon fluids that migrate upward will get higher amount of iso-alkanes and five-membered naphthenes. Chemical composition for individual hydrocarbons from oil and condensates from the Bulla-deniz, Khara-zire, Duvanny-deniz fields shows increase in distribution of n-alkanes and decreases of total amount of isoprenoids from top to bottom of the well section. That could be explained by the catagenetic processes (cracking). At the same time, we observe that ratio of low-molecular normal alkanes and isoprenoid hydrocarbons to high-

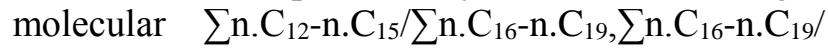
$\sum$ n. $C_{20}-$ n. $C_{25}$ and $\sum$ iso.C C $_{13}$-iso.C C $_{15} / \sum$ iso.C C $_{21}$-iso. $C_{25}$ in oils and condensates increases in all cases from the bottom to upper part of the section. A similar phenomenon is observed at the Bulla-deniz field: horizon $\mathrm{V}$ condensates contain a higher amount of the more mobile low-molecular n-alkanes and isoprenoids, in comparison to the condensates from the deeper horizon VII. Such changes are likely to be the result of differentiation of n.alkanes and isoprenoids caused by chromatography effect, as well as decrease in temperature and pressure along the migration path. Thus, changes in the individual composition of hydrocarbons could be explained by 2 factors: cracking and differentiation during vertical migration. It is important to highlight that pristane/ phytane ratio in condensates is higher than in oils. High ratios of pristane/phytane in some cases are associated by many researchers not only with genetic features of source rocks, but also with physical processes occurring at the time of formation of the hydrocarbon traps. Such changes are common for the CPI index of alkanes as well. All above suggest the dominant role of vertical migration in the formation of the hydrocarbon accumulations in Productive Series. There are direct evidences which demonstrate that the migration of hydrocarbon in the study area is still taking place. Analysis of the abnormal high pressure on the existing uplift zones indicates continued vertical fluid flow into Productive Series. However, it should be noted that lateral migration also plays a critical role in filling the reservoirs of the lower part of the Productive series. Oil to source rock correlation done on samples taken from the producing well in Sangachaly-deniz shows similarity in distribution of the key indicative biomarkers, including relative abundance of $\mathrm{C}_{27}: \mathrm{C}_{28}: \mathrm{C}_{29}$ regular steranes, rearranged steranes to regular steranes, tricyclicterpanes, pentacyclichopanes and other triterpanes. Correlation was done on Pliocene, Productive series age oil sample (Fig.8A) and Late Miocene, Diatomaceous shale sample from the same well (Fig 8B). Similarity in geochemical properties and distribution of the key biomarkers also suggests that oil and rock samples analyzed belong to the same (or similar) genetic family.

Table 2

Baku archipelago representative fields- Gasoline fractions (boiling point at $125^{\circ} \mathrm{C}$ ) composition and trends

\begin{tabular}{|c|c|c|c|c|c|c|c|c|c|c|c|c|c|}
\hline \multirow{2}{*}{ Field } & \multirow{2}{*}{ Horizon } & \multirow{2}{*}{ Type of accumulation } & \multirow{2}{*}{$\begin{array}{l}\text { Depth, } \\
\text { meter }\end{array}$} & \multicolumn{4}{|c|}{ n-alkanes/iso-alkanes } & \multicolumn{3}{|c|}{ Cyclohexane/Cyclopentane } & \multirow{2}{*}{\begin{tabular}{|c|} 
n-alkanes/ \\
iso-alkanes
\end{tabular}} & \multirow{2}{*}{\begin{tabular}{|l|} 
Cyclohexane \\
$\sum$ Cyclopentane
\end{tabular}} & \multirow{2}{*}{$\begin{array}{c}\text { Alkane/ } \\
\text { Cyclic }\end{array}$} \\
\hline & & & & $\mathrm{C}_{5}$ & $\mathrm{C}_{6}$ & $\mathrm{C}_{7}$ & $\mathrm{C}_{8}$ & $\mathrm{C}_{6}$ & $\mathrm{C}_{7}$ & $\mathrm{C}_{8}$ & & & \\
\hline \multirow{3}{*}{$\begin{array}{c}\text { Sangachaly-deniz- } \\
\text { Duvanny-deniz- } \\
\text { Khara-Zre } \\
\end{array}$} & $\mathrm{V}$ & Gas-Condensate-Oil & 3327 & 0.63 & 0.54 & 0.83 & 0.65 & 1.48 & 2.26 & 1.91 & 0.68 & 2.16 & 0.85 \\
\hline & VII & Gas-Oil & 3498 & 0.78 & 0.55 & 0.79 & 0.62 & 1.51 & 2.75 & 2.37 & 0.67 & 2.26 & 0.78 \\
\hline & VIII & Gas-Condensate & 5023 & 0.49 & 0.41 & 0.83 & 0.78 & 1.54 & 3.55 & 2.56 & 0,69 & 2.80 & 0.86 \\
\hline \multirow{3}{*}{ Bulla-deniz } & VII & Gas-Condensate & 5442 & 0.88 & 0.57 & 0.83 & 0.70 & 1.83 & 2.29 & 1.49 & 0.76 & 2.02 & 0.99 \\
\hline & VII & Gas-Condensate & 5459 & 0.73 & 0.53 & 0.75 & 0.67 & 2.15 & 2.38 & 1.66 & 0.67 & 2.10 & 0.97 \\
\hline & VII & Gas-Condensate & 5855 & 0.79 & 0.60 & 0.74 & 0.66 & 2.12 & 2.41 & 1.63 & 0.66 & 2.12 & 0.94 \\
\hline Alyaty-deniz & VII & Gas-Oil & 5108 & 0.73 & 0.51 & 0.68 & 0.62 & 2.21 & 2.50 & 1.66 & 0.61 & 2.21 & 0.77 \\
\hline
\end{tabular}



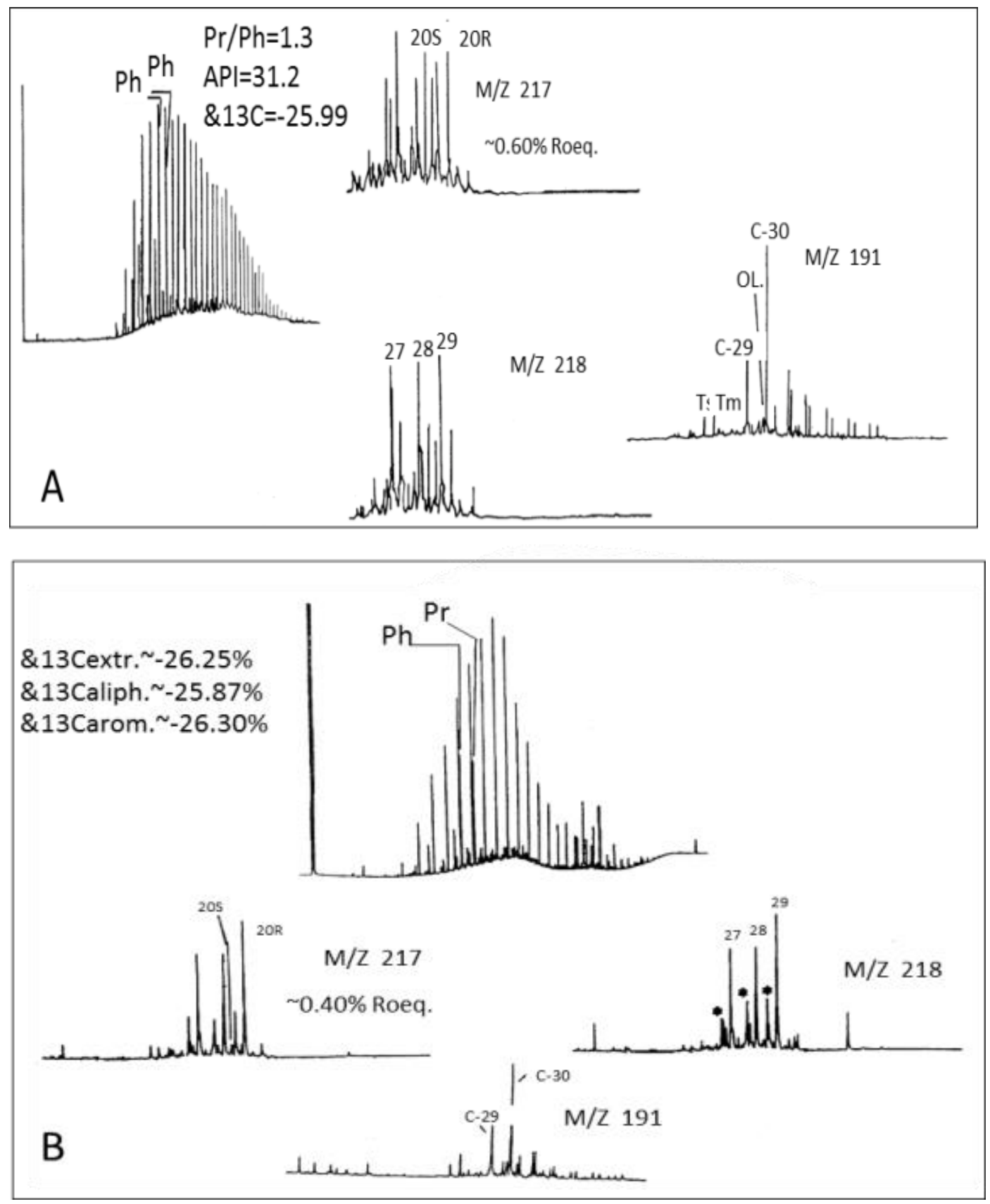

Fig. 8. Oil-Source rock correlation - Pliocene, Productive series age oil sample from Sangachaly-deniz field (A) and Late Miocene, Diatomaceous shale sample from the same well (B)

\section{Conclusion}

Detailed research work with most modern technologies applied helps to address subsurface uncertainties and challenges we face in oil and gas industry and in planning further exploration activities as well. Analytical studies and further interpretation of the data received suggest that hydrocarbons in the study area belong to the same or similar genetic family. Differences observed could be explained by the secondary processes, such as, biodegradation, washing and fractionation during migration and in the reservoir. Data suggests two episodes of petroleum generation in the area of study. An early, primary pulse of generation is regional and likely emanates from the Lower Maykop in the deep water portion of the study area. This generation occurs at preAkchagylian time during deposition of the Productive Series. This active generative window migrates up dip from the deep basin toward the productive Sangachaly-deniz - Duvanny-deniz - Khara-zire trend and non-productive southern structural trends. Assuming that structural growth along the productive Sangachaly trend predates the growth along some of the structures in the south, for example Hamadag trend, this early generated petroleum (and early expulsed petroleum as indicated by methyl- 
phenanthrene index and other measurements) can charge structures along the productive trend and to the east of it. Renewed sediment loading during the post-Akchagylian, drives a second, more focused pulse of petroleum generation. That supports hydrocarbon accumulation in the existing traps.

\section{REFERENCES}

Abrams M.A., Narimanov A.A. Geochemical evaluation of hydrocarbons and their potential sources in the western South Caspian depression, Republic of Azerbaijan. Marine and Petroleum Geology, Vol. 14, No. 4, 1997, pp. 451-468.

Chakhmakhchev V.A., Yushkevich G.N., Vinogradova T.L., Zhuze T.P. Va-riations in the composition of gas-condensate systems during migration. Geologiya nefti i gaza (Oil and gas geology), No. 2, 1974, pp. 45-50 (in Russian).

Goodwin N., Abdullayev N., Javadova A., Volk H., Riley G. Diamondoids and basin modeling reveal one of the world's deepest petroleum systems, South Caspian basin, Azerbaijan. Journal of Petroleum Geology, Vol. 43, No. 2, 2020, pp. 133-150.

Gubkin I.M. The doctrine of oil. Publication of ONTI. Moscow, 1937, 384 p. (in Russian).

Guliyev I.S., Martinova G.S., Babayev F. R., Javadova A.S. Adamandoids in oils as indicators of presence of the deep source rocks, Absheron archipelago, South Caspian Basin. Proceedings of National Academy of Sciences of Azerbaijan, Vol. LXXV, No. 1, 2019, pp. 57-61.

Guliyev I.S., Feyzullayev A.A., Huseynov D.A. Geochemical features and fluid sources of mud volcanoes of the South Caspian sedimentary basin in the light of new data on $\mathrm{C}, \mathrm{H}$ and O isotopy. Geochemistry, No. 7, 2004, pp. 792-800 (in Russian).

Grantham P.J., Wakefield L.L. Variations in the sterane carbon number distributions of marine source rock derived crude oils through geological time. Organic Geochemistry, Vol. 12, No. 1, 1988, pp. 61-73.

Grantham P.J. Sterane isomerisation and moretane/hopane ratios in crude oils derived from Tertiary source rocks. Organic Geochemistry, Vol. 9, No. 6, 1986, pp. 293-304.

Grantham P.J., Posthuma J., Baak A. Triterpanes in a number of Far Eastern crude oils. In book: Advances in Organic Geochemistry, Wiley, Chichester. 1983, pp. 675-683.

Green T., Abdullayev N., Hossack J., Riley G., Roberts A.M. Sedimentation and subsidence in the South Caspian Basin, Azerbaijan. Geological Society, London, Special Publications, Vol. 312, No. 1, 2009, pp. 241-260.

Javadova A.S. Javadova A.S. Geochemistry of petroleum systems of the Baku archipelago; predictions of hydrocarbon potential of deep horizons. Thesis for the degree of candidate of geological and mineralogical sciences. Funds of the Institute of Geology and Geophysics, ANAS. Baku, 2004, pp. 151-154 (in Russian).

Inan S., Yalcin M.N., Guliev I.S., Kuliev K., Feyzullayev A.A. Deep petroleum occurrences in the Lower Kura Depression, South Caspian Basin, Azerbaijan: an organic geochemical and basin modeling study. Marine and Petroleum Geology, Vol. 14, No. 7, 1997, pp. 731-762.

Mamedov G.A., Javadova A.S. Geochemical features of oils and condensates of Baku archipelago as indicators of depositional environment conditions. Ucheniye zapiski of Azerbaijan State Oil Academy, Baku, No. 3, 1993, pp. 3-7 (in Russian)

Narimanov A.A., Rinaldi G., Javadova A.S. Biomarker hydrocarbons studies and geological interpretation, South Caspian Depression, Azerbaijan. Extended abstract book of EAGE
Acknowledgment Author deeply appreciates help and support from colleagues and distinguished advisors during both analytical work and interpretation of the data received as well. Special thanks to Academicians I. Guliyev and A. Feyzullayev for reviewing the paper and valuable comments.

\section{ЛИТЕРАТУРА}

Abrams M.A., Narimanov A.A. Geochemical evaluation of hydrocarbons and their potential sources in the western South Caspian depression, Republic of Azerbaijan. Marine and Petroleum Geology, Vol. 14, No. 4, 1997, pp. 451-468.

Goodwin N., Abdullayev N., Javadova A., Volk H., Riley G. Diamondoids and basin modeling reveal one of the world's deepest petroleum systems, South Caspian basin, Azerbaijan. Journal of Petroleum Geology, Vol. 43, No. 2, 2020, pp. 133-150.

Guliyev I.S., Martinova G.S., Babayev F. R., Javadova A.S. Adamandoids in oils as indicators of presence of the deep source rocks, Absheron archipelago, South Caspian Basin. Proceedings of National Academy of Sciences of Azerbaijan, Vol. LXXV, No. 1, 2019, pp. 57-61.

Grantham P.J., Wakefield L.L. Variations in the sterane carbon number distributions of marine source rock derived crude oils through geological time. Organic Geochemistry, Vol. 12, No. 1, 1988, pp. 61-73.

Grantham P.J. Sterane isomerisation and moretane/hopane ratios in crude oils derived from Tertiary source rocks. Organic Geochemistry, Vol. 9, No. 6, 1986, pp. 293-304.

Grantham P.J., Posthuma J., Baak A. Triterpanes in a number of Far Eastern crude oils. In book: Advances in Organic Geochemistry, Wiley, Chichester. 1983, pp. 675-683.

Green T., Abdullayev N., Hossack J., Riley G.,Roberts A.M. Sedimentation and subsidence in the South Caspian Basin, Azerbaijan. Geological Society, London, Special Publications, Vol. 312, No. 1, 2009, pp. 241-260.

Narimanov A.A., Rinaldi G., Javadova A.S. Biomarker hydrocarbons studies and geological interpretation, South Caspian Depression, Azerbaijan. Extended abstract book of EAGE 59th Conference and Technical Exhibition, Geneva, Switzerland, 1997, 26-30 May, p. 87.

Inan S., Yalcin M.N., Guliev I.S., Kuliev K., Feyzullayev A.A. Deep petroleum occurrences in the Lower Kura Depression, South Caspian Basin, Azerbaijan: an organic geochemical and basin modeling study. Marine and Petroleum Geology, Vol. 14, No. 7, 1997, pp. 731-762.

Peters K.E., Moldowan J.M. The biomarker guide: interpreting molecular fossils in petroleum and ancient sediments. Prentice Hall. Englewood Cliffs, New Jersey, USA, 1993, 363 p.

Radke M., Welte D. The Methylphenanthrene Index (MPI): A maturity parameter based on aromatic hydrocarbons. Advances in Organic Geochemistry, Wiley, Chichester. 1983, pp. 504-512.

Reynolds A.D., Simmons M.D., Bowman M.B., Henton J., Brayshaw A.C., Ali-Zade A.A., Guliev I.S., Suleymanova S.F., Ataeva E.Z., Mamedova D.N., Koshkarly R.O. Implications of outcrop geology for reservoirs in the Neogene Productive Series: Absheron Peninsula, Azerbaijan. American Association of Petroleum Geologists Bulletin, Vol. 82, 1998, pp. 25-49.

Riva A., Caccialanza P.G., Quagliaroli F. Recognition of $18 \beta$ (H)oleanane in several crudes and Tertiary-Upper Cretaceous sediments. Definition of a new maturity parameter. Organic Geochemistry, Vol. 13, No. 4-6, 1988, pp. 671-675.

Seifert W.K., Moldowan J.M. The effect of thermal stress on source-rock quality as measured by hopane stereochem- 
$59^{\text {th }}$ Conference and Technical Exhibition, Geneva, Switzerland, 1997, 26-30 May, pp.87.

Nikonov V.F. Study of gas-condensate fields. Nedra. Moscow, 1962, 87 p. (in Russian).

Peters K.E., Moldowan J.M. The biomarker guide: interpreting molecular fossils in petroleum and ancient sediments. Prentice Hall. Englewood Cliffs, New Jersey, USA, 1993, 363 p.

Petrov A.A., Zakharenko V.A., Bryanskaya E.K. Variations in benzene fractions as indicators of oil metamorphism processes. In: Genesis of oil and gas. Nedra. Moscow, 1967, pp. 97-84 (in Russian).

Radke M., Welte D. The Methylphenanthrene Index (MPI): A maturity parameter based on aromatic hydrocarbons. Advances in Organic Geochemistry, Wiley, Chichester. 1983, pp. 504-512.

Reynolds A.D., Simmons M.D., Bowman M.B.,Henton J., Brayshaw A.C., Ali-Zade A.A., Guliev I.S., Suleymanova S.F., Ataeva E.Z., Mamedova D.N., Koshkarly R.O. Implications of outcrop geology for reservoirs in the Neogene Productive Series: Absheron Peninsula, Azerbaijan. American Association of Petroleum Geologists Bulletin, Vol. 82, 1998, pp. 25-49.

Riva A., Caccialanza P.G., Quagliaroli F. Recognition of $18 \beta$ (H)oleanane in several crudes and Tertiary-Upper Cretaceous sediments. Definition of a new maturity parameter. Organic Geochemistry, Vol. 13, No. 4-6, 1988, pp. 671-675.

Seifert W.K., Moldowan J.M. The effect of thermal stress on sourcerock quality as measured by hopane stereochemistry. Physics and Chemistry of the Earth, Vol. 12, 1980, pp. 229-237.

Starobinets I.S. Geological and geochemical features of gascondensates. Nedra. Leningrad, 1974, 47 p. (in Russian).

ten Haven H.L., Rullkotter J. The diagenetic fate of taraxer-14 ene and oleanene isomers. Geochimica et Cosmochimica Acta, Vol. 52, No. 10, 1988, pp. 2543-2548.

Volkman J.K. A review of sterol markers for marine and terrigenous organic matter. Organic Geochemistry, Vol. 9, No. 2, 1986, pp. 83-99.

Whitehead E.V. Molecular evidence for the biogenesis of petroleum and natural gas. In: (Ingerson E., ed.) Proceedings of symposium on hydrogeochemistry and biogeochemistry, International association of geochemistry and cosmochemistry, Vol. 2, 1973, Clarke Company. Washington, DC, pp. 158-211.

Zonenshain L.P., Le Pichon X. Deep basins of the Black Sea and Caspian Sea as remnants of Mesozoic back-arc basins. Tectonophysics, Vol. 123, No. 1-4, 1986, pp. 181-211. istry. Physics and Chemistry of the Earth, Vol.12, 1980, pp. 229-237.

ten Haven H.L., Rullkotter J. The diagenetic fate of taraxer-14ene and oleanene isomers. Geochimica et Cosmochimica Acta, Vol. 52, No. 10, 1988, pp. 2543-2548.

Volkman J.K. A review of sterol markers for marine and terrigenous organic matter. Organic Geochemistry, Vol. 9, No. 2, 1986, pp. 83-99.

Whitehead E.V. Molecular evidence for the biogenesis of petroleum and natural gas. In: (Ingerson E., ed.) Proceedings of symposium on hydrogeochemistry and biogeochemistry, International association of geochemistry and cosmochemistry, Vol. 2, 1973, Clarke Company. Washington, DC, pp. 158-211.

Zonenshain L.P., Le Pichon X. Deep basins of the Black Sea and Caspian Sea as remnants of Mesozoic back-arc basins. Tectonophysics, Vol. 123, No. 1-4, 1986, pp. 181-211.

Губкин И.М. Учение о нефти. Изд. ОНТИ. Москва, 1937, $384 \mathrm{c}$.

Гулиев И.С., Фейзуллаев А.А., Гусейнов Д.А. Геохимические особенности и источники флюидов грязевых вулканов Южно-Каспийского осадочного бассейна в свете новых данных по изотопии $\mathrm{C}, \mathrm{H}$ и О. Геохимия, No.7, 2004 , c. $792-800$

Джавадова А.С. Геохимия углеводородных систем Бакинского архипелага с прогнозом нефтегазоносности глубокопогруженных отложений. Диссертация на соискание ученой степени кандидата геолого-минералогических наук. Фонды Института геологии и геофизики НАНА, Баку, 2004, с. 151-154.

Мамедов Г.А., Джавадова А.С. Геохимические особенности нефтей и конденсатов Бакинского архипелага как отражение условий формирования их состава. Ученые записки Азерб. Госуд. Нефтяной Академии, Баку, No. 3 , 1993, с. 3-7.

Никонов В.Ф. Изучение газоконденсатных месторождений. Недра. Москва, 1962, 87 с.

Петров Ал.А., Захаренко В.А., Брянская Э.К. Закономерности в составе бензиновых фракций как отражение процессов метаморфизма нефтей. В сб.: Генезис нефти и газа, Недра. Москва, 1967, с. 97-84.

Старобинец И.С. Геолого-геохимические особенности газоконденсатов. Недра. Ленинград, 1974, 47 с.

Чахмахчев В.А., Юшкевич Г.Н., Виноградова Т.Л., Жузе Т.П. Изменение состава газоконденсатных систем при их миграции. Геология нефти и газа, No. 2, 1974, с. 45-50.

\title{
ХАРАКТЕРИСТИКА НЕФТЕМАТЕРИНСКИХ ПОРОД И ГЕНЕРАЦИЯ УГЛЕВОДОРОДОВ, БАКИНСКИЙ АРХИПЕЛАГ, ЮЖНО-КАСПИЙСКИЙ БАССЕЙН, АЗЕРБАЙДЖАН
}

\author{
Джавадова А.C. \\ Институт нефти и газа НАН Азербайджана \\ AZ1000, Баку, ул.Ф.Амирова, 9: ajavadova@yahoo.com
}

Резюме. Бассейн южного Каспия (ЮКБ) известен как один из старейших нефтедобывающих регионов в мире. Несмотря на более чем 100-летнюю историю геологоразведки и разработки углеводородов, в недрах бассейна всё ещё остаются большие запасы неразведанных углеводородных ресурсов. До настоящего времени было осуществлено большое количество исследовательских проектов, которые помогли лучше понять историю развития бассейна и тем самым оценить и раскрыть имеющийся углеводородный потенциал. Это, несомненно, сыграло решающую роль в работах по геолого-геофизическому и геохимическому картированию региона, подняв на более детальный и достоверный уровень результаты проведённых работ. Доступ к достоверным геологическим, сейсмическим и скважинным данным, полученным в результате недавних геологоразведочных работ в неразведанных до сих пор районах, позволил лучше понять природу, характер распределения ключевых геолого-геофизических, геохимических параметров, которые играют существенную роль при планировании будущих программ по геологоразведке и разработке отдельных перспективных районов в регионе, и сконцентрироваться на потенциально приоритетных районах.

Целью данной статьи является представление результатов геохимических исследований, геолого-геохимического анализа, корреляций в системе нефть - порода - грязевые вулканы - скважинные данные, проведенных с целью описания истории формирования углеводородных флюидов в бассейне, потенциальных механизмов генерации и миграции углеводородов, 


\title{
Geology and geophysics
}

геологического времени формирования и заполнения структурных ловушек. Геолого-геохимический анализ полученных данных поддерживает ранее высказанное мнение о глубинном происхождении и генетическом единстве исследуемых углеводородов. Генерация углеводородов и миграционные процессы в этом районе контролируются режимом давления в нефтематеринских породах по отношению к окружающим их проницаемым породам. Влияние глинистых покрышек на характер распределения в и тип углеводородных флюидов в районе исследования подтверждается изменениями, наблюдаемыми в компонентном и углеводородном составе нефтей по разрезу месторождений. Время генерации углеводородных флюидов из нефтематеринских пород согласуется со временем образования самих структурных ловушек в районе исследования.

Ключевые слова: нефть, газ, источник формирования, геохимические исследования, биомаркеры, миграчия, ЮжноКаспийский бассейн

\section{NEFT-ANA SÜXURLARININ XÜSUSIYYӘTLӘRI Və KARBOHIDROGENLӘRIN GENERASIYASI, BAKI ARXIPELAQI, CONUBİ XəZӘR HÖVZOSİ, AZORBAYCAN}

\author{
Cavadova A.S. \\ AMEA Neft va GazInstitutu \\ AZ1000, Bakı şəh.,F.Әmirov küç.,9: ajavadova@yahoo.com
}

\begin{abstract}
Xülasə. Cənubi Xəzər Hövzəsi (CXH) dünyanın ən qədim karbohidrogen bölgələrindən biridir. Qeyd etmək lazımdır ki, 100 ildən artıq neft və qaz sənayesinə malik Cənubi Xəzər Hövzəsində hələ də böyük həcmdə aşkar olunmamış neft və qaz ehtiyatları var. Məlumdur ki, burada bu günə gədər çox sayda elmi-tədqiqat işləri aparılmışdır. Aparılan işlərin məqsədi Cənubi Xəzər Hövzəsinin yaranma tarixinin öyrənilməsini daha dəqiq təsvir etməklə, tədqiqat sahəsinin karbohidrogen ehtiyatlarının qiymətləndirilməsi və aşkar edilməsi olmuşdur. Son illər Cənubi Xəzər Hövzəsində bu günə gədər öyrənilməmiş sahələrdə geoloji-kəşfiyyat işləri aparılmışdır. Nəticədə yeni geoloji-geofiziki məlumatların əldə edilməsi mümkün olmuşdur ki, bu da, şübhəsiz, çox vacib bir haldır. Burada yeni seysmik məlumatlarla yanaşı, quyu məlumatlarındandan söhbət gedir ki, bu da, hövzənin ayrı-ayrı sahələrinin geoloji xəritəalmasında aparılan işlərin daha dolğun, etibarlı nəticələnməsinə gətirib çıxarmışdır. Eyni zamanda, daha etibarlı, dolğun məlumatların əldə edilməsi hövzədə, onun ayrı-ayrı perspektiv sahələrində geoloji-kəşfiyyat, aşkar olunmuş yataqların istismar işlərinin planlaşdırılmasında mühüm rol oynayan geoloji-geofiziki parametrlərin daha düzgün təsvir edilməsində əvəzolunmaz amildir. Nəticədə planlaşdırmanın daha məqsədyönlü aparılmasının təşkil edilməsi mümkün olmuşdur. Təqdim olunan məqalədə aparılmış geoloji və geokimyəvi tədqiqatların nəticələri, neft, ana süxur, palçıq vulkanları və quyu məlumatlarından istifadə etməklə hövzədə karbohidrogenlərin yaranma tarixi, generasiya və miqrasiya mexanizmləri, karbohidrogenlərin əmələgəlmə və struktur tələlərin dolma zamanına dair məlumatlar təsvir edilmişdir. Geokimyəvi məlumatların nəticəsi tədqiqat sahəsində toplanmış karbohidrogenlərin dərin, eyni və ya yaxın mənşəli olmasını göstərir. Karbohidrogen flüidlərinin generasiya və migrasiyası, əsasən ana süxurlarda olan təyziqlərin ətraf keçirici süxurlara olan nisbəti ilə əlaqəsi göstərilmişdir. Gil örtük suxurlarının keyfiyyətinin karbohidrogen fluidlərinin paylanmasına və faza növlərinə təsirinin önəmliyi yataqlarda neftlərin komponent və karbohidrogen tərkibində müşahidə olunan dəyişikliklərdə öz əksini tapmışdır. Karbohidrogenlərin ana süxurlardan generasiya etməsi və tədqiqat sahəsində struktur tələlərin yaranması eyni geoloji zamanda baş vermişdir.
\end{abstract}

Açar sözlər: neft, qaz, amələgalmə mənbəyi, geokimyəvi tədqiqatlar, biomarkerlar, miqrasiya, Cənubi Xəzər hövzəsi 